\title{
Austroeupatorium inulifolium invasion increases arbuscular mycorrhizal abundance in Cymbopogon-dominated grasslands in Knuckles Conservation Area
}

\author{
H.M.S.P. Madawala \\ Department of Botany, Faculty of Science, University of Peradeniya, Peradeniya.
}

\begin{abstract}
Plant invasions can interfere with above- and belowground dynamics of ecosystems, which eventually alter the ecosystem functions. However, relatively less attention has been drawn to assess the impacts of invasion on the soil microbial community. Austroeupatorium inulifolium has been spreading into different landuse types in the Knuckles Conservation Area (KCA) for the last few years, including Cymbopogondominated grasslands. Therefore, the study investigated whether this invasion has altered the arbuscular mycorrhizal fungal (AMF) abundance and the diversity in these grasslands through isolation and identification of AMF spores in three different habitats, namely less- and highly-invaded grasslands (LIG and HIG, respectively) and nearby lower montane forest patch (LMF), which is free of Austroeupatorium invasion. The results revealed that the invasion has significantly increased the AMF spore abundance. However, the LMF reported the highest AMF diversity compared to invaded grasslands. AMF richness showed no difference between the habitats. The results highlighted the importance of investigating the changes caused to the soil microbial community due to invasions and their implications for site restoration.
\end{abstract}

Keywords: Arbuscular mycorrhizae, diversity, exotic plants, invasion, root colonization.

\section{INTRODUCTION}

Exotic plant invasions are often associated with marked shifts in the vegetation structure and composition in their introduced range (Levine et al., 2003). However, only a few attempts have been made to study the potential alterations of soil microbial communities that may be associated with such vegetation changes. Exotic plant invasions could alter the composition and functions of the soil microbial community due to changes in plant inputs to the soil (van der Putten et al., 2007). It is well known that belowground biotic interactions play a major role in plant distribution and ecosystem functions (Bever et al., 1997; Stinson et al., 2006). Therefore, it is of critical importance to understand the impacts of invasions on the soil microbial communities.

Among soil microorganisms, arbuscular mycorrhizal fungi (AMF) play a vital role in sustaining the plant growth in an ecosystem. Sanon et al. (2012) observed a clear reduction of the AMF density in soil invaded by the exotic plant Amaranthus viridis when compared with an un-invaded soil nearby. On the contrary, Lekberg et al. (2013) observed an increase in the AMF abundance and diversity in grass-dominated communities invaded by the exotics, Centaurea stoebe and Euphorbia esula. For the past few years, many land-use types in the KCA including man-made grasslands have been invaded by an exotic shrub, Austroeupatorium inulifolium. Studies showed that Austroeupatorium invasion has not only altered the structure and diversity of these grassland communities but also the soil fertility levels, litter loading and decomposition rates as well (Piyasinghe et al., 2013). The present study investigated whether the $A$. inulifolium invasion has altered the AMF abundance and diversity in Cymbopogon-dominated grasslands in the Knuckles Conservation Area (KCA) in Sri Lanka.

\section{METHODS AND MATERIALS}

The study took place in highly degraded, man-made grasslands at Riverston in the KCA, Sri Lanka. For the present study, 3 plant communities were selected: 
two grassland communities with different levels of Austroeupatorium invasion (less- and highly-invaded grasslands, hereafter referred to as LIG and HIG, respectively) and a lower-montane forest (LMF) patch bordering these grasslands. From each of the plant community (LIG, HIG and LMF) dominated by Cymbopogon nardus, Austroeupatorium and native plant species, respectively 10 composite soil samples were taken within $500 \mathrm{~m}$ of each other. Based on the visual observations, LIG and HIG had an invasive coverage of $<30$ and $>80 \%$, respectively. The forest-grassland edge had an Austroeupatorium coverage of $<5 \%$, which decreased rapidly towards the forest interior (Haluwana \& Madawala, 2013). Some basic soil chemical properties of the 3 vegetation types are given in the Table 1 . Root samples of Austroeupatorium and Ageratina riparia (another exotic invasive plant dominating the ground layer of LMF) were extracted and preserved in $70 \%$ ethyl alcohol until processed.

Table 1: Basic soil chemical parameters at the study sites

\begin{tabular}{llll}
\hline Soil parameters & $\mathrm{LIG}^{*}$ & $\mathrm{HIG}^{*}$ & $\mathrm{LMF}^{\#}$ \\
\hline Soil pH & $5.48 \pm 0.11^{\mathrm{b}}$ & $5.91 \pm 0.27^{\text {a }}$ & $5.5 \pm 0.04$ \\
Total C (\%) & $4.20 \pm 0.22^{\text {a }}$ & $4.22 \pm 0.29^{\text {a }}$ & $4.8 \pm 0.01$ \\
Total N (\%) & $0.37 \pm 0.09^{\mathrm{b}}$ & $0.44 \pm 0.10^{\text {a }}$ & $0.085 \pm 0.001$ \\
Total P (\%) & $0.099 \pm 0.01^{\text {a }}$ & $0.098 \pm 0.02^{\text {a }}$ & $0.065 \pm 0.001$ \\
\hline
\end{tabular}

Significant differences were indicated using different letters following one-way ANOVA. LMF not included in the analysis. Average values $(\mathrm{n}=18)^{*}$ are indicated with standard errors of mean.

* Piyasinghe et al. (2013)

* Gunaratne et al. (2010)

The soil samples were analyzed to determine the total number of AMF spores in $100 \mathrm{~g}$ of dry soil using wet sieving and decanting, followed by sucrose centrifugation. Spores (categorized into 45, 63 and $125 \mu \mathrm{m}$ diameter classes) were counted under a compound microscope and different morphotypes were identified to the genus level with the aid of the descriptions available at http://invam. caf.Wvu.edu_info/Taxonomy/species.htm. The roots of Austroeupatorium and A. riparia were cleared in $10 \%$ $\mathrm{KOH}$, stained with $0.05 \% \mathrm{w} / \mathrm{v}$ trypan blue (Kormanik \& McGraw, 1982) and the percentage colonization of AMF (McGonigle et al., 1990) was determined.

Using the spore counts and different spore morphotypes, the species density (number of AMF spores present in $100 \mathrm{~g}$ of dry soil), species richness (number of AMF morphotypes present in $100 \mathrm{~g}$ of dry soil) and diversity indices such as Simpson's dominance index (Is) and Shannon's diversity index (H) were calculated. Evenness values [evenness $=\mathrm{H} / \mathrm{Ln}$ (number of morphotypes)] were also calculated. Percentage root colonization was estimated by the number of cells infected over the total number of cells counted. AMF spore data were statistically analyzed using ANOVA in Minitab 16.0. The means were separated using Tukey's test. Root colonization percentages were compared using a t-test with arcsine transformed data.

\section{RESULTS}

A total of 31 AMF morphotypes were detected in all three study sites. Out of this, 24 morphotypes were identified to their generic levels, while 7 remained as un-identified. A total of 30, 29 and 28 morphotypes (belonging to three different size classes) were isolated from LIG, HIG and LMF, respectively. Out of the 30 morphotypes at LIG, 7 Glomus $(74.0 \%$ of the total isolates of LIG), 12 Scutellospora $(17.6 \%)$ and 4 Gigaspora $(7.1 \%$ of immature spores) species were recorded. There were seven un-identified morphotypes (1.3\%). In HIG, 7 Glomus (65.7\%) 12 Scutellospora (28.9\%), 4 Gigaspora (3.7\%) species and 6 unidentified morphotypes (1.8\%) were recorded. In LMF, 7 Glomus (51.1 \%), 13 Scutellospora $(24.3 \%), 4$ Gigaspora $(23.0 \%)$ species and 4 unidentified morphotypes $(1.67 \%)$ were detected.

The highest number of spores $(15,439)$ was recovered from HIG, followed by LIG and LMF (11,480 and 2,808, respectively). The average spore counts (abundance) were significantly higher in both invasive grasslands (LIG and HIG) compared to that of the LMF (one-way ANOVA; $\mathrm{df}=9, \mathrm{~F}=6.36, \mathrm{p}=0.003$ ). The abundance of AMF spores in forest soils was markedly low. Spore size distribution also varied among the three vegetation types. The total spore count was significantly dominated by medium-sized spores $(63 \mu \mathrm{m})$ in both LIG and HIG $(\approx 79$ and $64 \%$, respectively) but not in LMF (45\%). In all three vegetation types, the lowest contribution to the total spore count was from the large-sized spores $(125 \mu \mathrm{m})(\approx 4,3$ and $12 \%$ in LIG, HIG and LMF, respectively). Small- and large-sized spore counts (45 and $125 \mu \mathrm{m}$ ) showed no significant differences among the vegetation types (Figure 1).

The average number of spore morphotypes (richness) demonstrated no significant difference between the vegetation types (Figure 2). However, large-sized spore morphotypes were significantly less in all vegetation types studied compared to that of small- and mediumsized spores. 


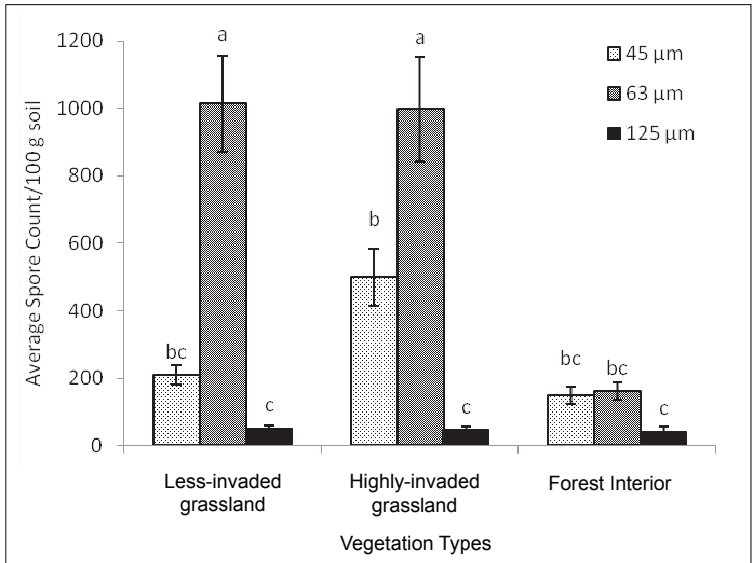

Figure 1: Average arbuscular mycorrhizal fungal spore counts in lessinvaded and highly-invaded grasslands, and lower montane forest soils (LIG, HIG and LMF, respectively) at the Knuckles Conservation Area, Sri Lanka. Bars with different letters indicate significant differences at $\mathrm{p} \leq 0.001$ (two-way ANOVA; $\mathrm{df}=9, \mathrm{~F}=18.8$ and 51.6 for vegetation type and spore size, respectively).

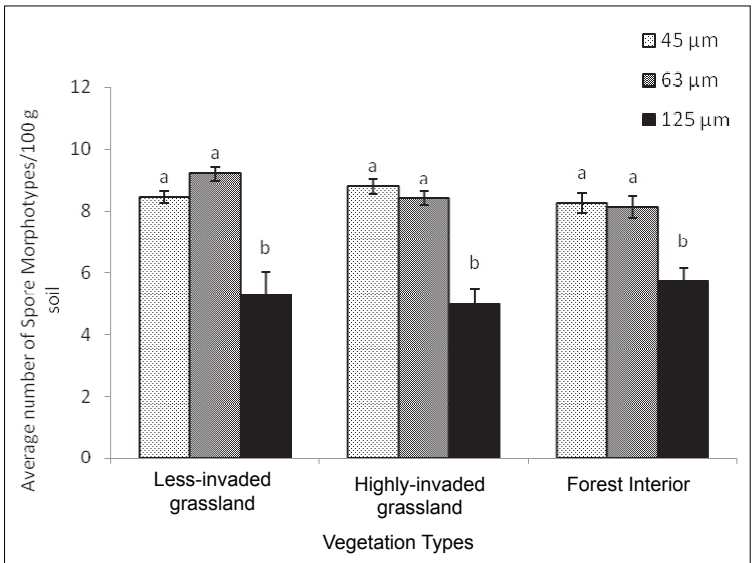

Figure 2: Average number of arbuscular mycorrhizal spore morphotypes under each spore size category $(45,63$ and $125 \mu \mathrm{m})$ in less-invaded, highly-invaded and lower montane forest soils at the Knuckles Conservation Area, Sri Lanka. Bars with different letters indicate significant differences at $\mathrm{p} \leq 0.001$ (two-way ANOVA; $\mathrm{df}=9, \mathrm{~F}=69.4$ spore size).

Table 2: Total number of arbuscular mycorrhizal spores, spore morphotypes, diversity indices (Shannon's and Simpson's diversity indices) and evenness values in the three vegetation types studied (less-invaded grassland, highly-invaded grassland and lower-montane forest) at the Knuckles Conservation Area, Sri Lanka.

\begin{tabular}{lccc}
\hline & $\begin{array}{c}\text { Less-invaded } \\
\text { grassland } \\
(\mathrm{LIG})\end{array}$ & $\begin{array}{c}\text { Highly-invaded } \\
\text { grassland } \\
\text { (HIG) }\end{array}$ & $\begin{array}{c}\text { Lower-montane } \\
\text { forest } \\
\text { (LMF) }\end{array}$ \\
\hline Total number of spores & 11,480 & 15,439 & 2,808 \\
Number of spore morphotypes & 30 & 29 & 28 \\
Simpson's diversity index & 0.787 & 0.849 & 0.906 \\
Shannon's diversity index & 2.059 & 2.271 & 2.682 \\
Evenness & 0.605 & 0.674 & 0.805 \\
\hline
\end{tabular}

In spite of the low spore abundance, LMF showed a higher AMF diversity compared to invaded grasslands, HIG and LIG (Table 2). Austroeupatorium roots showed a poor AMF colonization (9\%) compared to that of A. riparia $(28 \%)$.

\section{DISCUSSION}

The present study investigated the alterations of AMF abundance, richness and diversity due to the Austroeupatorium inulifolium invasion. The results showed that AMF spore abundance was significantly higher in invaded grasslands (both LIG and HIG) indicating the ability of the invaded grassland community to support a high AMF population compared to that of the native, mixed plant community present in the forest nearby. The root colonization data revealed that Austroeupatorium is not a good host for AMF. Previous studies have also shown that most invaders are either non-mycorrhizal or have a low inherent dependency on mycorrhizae (van der Putten et al., 2007; Seifert et al., 2009). The high abundance and richness of forbs observed in the Austroeupatorium-invaded grasslands (Haluwana \& Madawala, 2013) may have contributed to 
the high AMF abundance in these grasslands. The ability of forbs to harbour AMF has been reported by Wilson and Harnett (1998). The present results also support the fact that AMF abundance would differ among different plant communities possibly due to the variations in host quality.

Contrary to the thinking that AMF richness may decrease due to the dominance of a single plant species and the reduction of AMF niches, all three vegetation types in this study showed a similar AMF spore richness. However, in all three vegetation types, large-sized spores contributed less to the AMF richness compared to small- and medium-sized spores. Lekberg et al. (2013) observed an increase in both AMF abundance and richness followed by an invasion in rangelands in the USA. However, the present results demonstrated that plant diversity is not always the determining factor for AMF richness as suggested by previous studies (Landis et al., 2004; Lekberg et al., 2013). The changes in supply of resources might be the main driving force behind soil microbial diversity (Waldrop et al., 2006). In spite of the low AMF spore abundance, LMF had the highest AMF diversity compared to invaded grasslands. The present results support the positive relationship between aboveand below-ground diversity.

In summary, the results showed that invaded grasslands have the ability to harbour higher AMF populations than multi-species forests, possibly due to the higher abundance of mycorrhizal forbs. However, plant diversity may be a strong predictor of AMF diversity. This study confirms that Austroeupatorium invasion has altered the soil microbial community, which could further enhance invasion and ensuing impacts on the ecosystem.

\section{REFERENCES}

1. Bever J.D., Westover K.M. \& Antonovics J. (1997). Incorporating the soil community into population dynamics: the utility of the feedback approach. Journal of Ecology $\mathbf{8 5}$ : $561-573$.

DOI: http://dx.doi.org/10.2307/2960528

2. Gunaratne A.M.T.A., Alexander I.J., Gunatilleke C.V.S., Gunatilleke I.A.U.N., Madawala Weerasinghe H.M.S.P. \& Burslem D.F.R.P. (2010). Barriers to tree seedling emergence on human-induced grasslands in Sri Lanka. Journal of Applied Ecology 47(1): 157 - 165. DOI: http://dx.doi.org/10.1111/j.1365-2664.2009.01763.x

3. Haluwana N. \& Madawala H.M.S.P. (2013). Changes in plant diversity and composition across forest edges bordered by Austroeupatorium inulifolium invaded grasslands in the Knuckles Conservation Area, Sri Lanka. Ceylon Journal of Science (Biological Sciences) 42(2): $29-43$.

4. http://invam.caf.Wvu.edu_info/Taxonomy/species.htm, Accessed 10 October 2013.
5. Kormanik P.P. \& McGraw A.C. (1982). Quantification of vesicular-arbuscular mycorrhiza in plant roots. Methods and Principles of Mycorrhizal Research (ed. N.C. Schenck) pp. 37 - 45. American Phytopathological Society, St. Paul, Minnasota, USA.

6. Landis F.C., Gargas A. \& Givnish T.J. (2004). Relationships among arbuscular mycorrhizal fungi, vascular plants and environmental conditions in oak savannas. New Phytologist 164: $493-504$.

DOI: http://dx.doi.org/10.1111/j.1469-8137.2004.01202.x

7. Lekberg Y., Gibbons S.M., Rosendahl S. \& Ramsey P.W. (2013). Severe plant invasions can increase mycorrhizal fungal abundance and diversity. International Society of Microbial Ecology 7: 1424 - 1433.

8. Levine J.M., Vila' M., D’Antonio C.M., Dukes J.S., Grigulis K. \& Lavorel S. (2003). Mechanisms underlying the impacts of exotic plant invasions. Proceedings of the Royal Society B: Biological Sciences 270: 775 - 781. DOI: http://dx.doi.org/10.1098/rspb.2003.2327

9. McGonigle T.P., Miller M.H., Evans D.G., Fairchild G.L. \& Swan J.A. (1990). A new method which gives an objective measure of colonization of roots by vesicular-arbuscular mycorrhizal fungi. New Phytologist 115: 495 - 501. DOI: http://dx.doi.org/10.1111/j.1469-8137.1990.tb00476.x

10. Piyasinghe I., Gunatilake J. \& Madawala H.M.S.P. (2013). Comparative study of litter quality, decay rates and nutrient fluxes of invasive species, Austroeupatorium inulifolium and Cymbopogon nardus. Proceedings of the International Forestry and Environment Symposium 2013, Department of Forestry and Environmental Science, University of Sri Jayewardenepura, Sri Lanka, 10 - 11 January.

11. Sanon A., Beguiristainm T., Cebron A., Berthelin J., Sylla S.N. \& Duponnois R. (2012). Differences in nutrient availability and mycorrhizal infectivity in soils invaded by an exotic plant negatively influence the development of indigenous Acacia species. Journal of Environmental Management 95: 275 - 279.

DOI: http://dx.doi.org/10.1016/j.jenvman.2011.01.025

12. Seifert E.K., Bever J.D. \& Maron J.L. (2009). Evidence for the evolution of reduced mycorrhizal dependence during plant invasion. Ecology 90: 1055 - 1062. DOI: http://dx.doi.org/10.1890/08-0419.1

13. Stinson K.A., Campbell S.A., Powell J.R., Wolfe B.E., Callaway R.M., Thelen G.C., Hallett S.G., Prati D. \& Klironomos J.N. (2006). Invasive plant suppresses the growth of native tree seedlings by disrupting belowground mutualisms. PLOS Biology 4: 727 - 731 .

DOI: http://dx.doi.org/10.1371/journal.pbio.0040140

14. van der Putten W.H., Klironomos J.N. \& Wardle D.A. (2007). Microbial ecology of biological invasions. Multidisciplinary Journal of Microbial Ecology 1: $28-37$.

15. Waldrop M.P., Zak D.R., Blackwood C.B., Curtis C.D. \& Tilman D. (2006). Resource availability controls fungal diversity across a plant diversity gradient. Ecological Letters 9: 1127 - 1135 .

DOI: http://dx.doi.org/10.1111/j.1461-0248.2006.00965.x

16. Wilson G.W. \& Harnett D.C. (1998). Interspecific variation in plant responses to mycorrhizal colonization in tallgrass prairie. American Journal of Botany 85: 1732 - 1738. DOI: http://dx.doi.org/10.2307/2446507 